\title{
ANTIBACTERIAL POTENTIAL OF NATIVE PLANTS FROM THE CAATINGA BIOME AGAINST Staphylococcus spp. ISOLATES FROM SMALL RUMINANTS WITH MASTITIS ${ }^{1}$
}

\author{
RODOLFO DE MORAES PEIXOTO ${ }^{2 *}$, WELLINGTON ERASMO LIMA E SILVA ${ }^{3}$, JACKSON ROBERTO GUEDES \\ SILVA ALMEIDA ${ }^{3}$, ALEXSANDRO BRANCO ${ }^{4}$, MATEUS MATIUZZI DA COSTA ${ }^{3}$
}

\begin{abstract}
The aim of the present study is to assess the antibacterial potential of plants from the Caatinga biome of the semi-arid region of Pernambuco, against Staphylococcus spp. isolates from cases of subclinical mastitis in small ruminants, such as goats and ewes. Ethanolic extracts of the following plants from the Caatinga biome were used: Encholirium spectabile Mart., Bromelia laciniosa Mart., Neoglaziovia variegata Mez., Amburana cearensis (Fr. Allem.) A.C.Smith, Hymenaea martiana Hayne, and Selaginella convoluta Spring. The presence of phenolic components, flavonoids, steroids, and terpenoids was verified for all the tested extracts. The mean minimal bactericide concentrations of the extracts of E. spectabile, B. laciniosa, and $N$. variegate were $11,379,11,405$, and $11,995 \mu \mathrm{g} / \mathrm{mL}$, respectively. The highest inhibitory activities were observed for $A$. cearensis and H. martiana, which inhibited 88.1 and $99.4 \%$ of the isolates, respectively. Other studies focusing on in vitro and in vivo activities should be undertaken.
\end{abstract}

Keywords: Natural extract. Goats. Ewes. Intramammary infection. Therapy.

\section{POTENCIAL ANTIBACTERIANO DE PLANTAS NATIVAS DO BIOMA CAATINGA FRENTE A Staphylococcus spp. ISOLADOS DE MASTITE EM PEQUENOS RUMINANTES}

RESUMO - Objetivou-se avaliar o potencial antibacteriano de plantas do bioma Caatinga do semi-árido pernambucano contra Staphylococcus spp. isolados de casos de mastite subclínica em pequenos ruminantes. Foram utilizados seis extratos etanólicos de plantas existentes no bioma Caatinga do semiárido Pernambucano, como Encholirium spectabile Mart., Bromelia laciniosa Mart., Neoglaziovia variegata Mez., Amburana cearensis (Fr. Allem.) A.C.Smith, Hymenaea martiana Hayne. e Selaginella convoluta Spring. Observou-se a presença de compostos fenólicos, flavonoides, esteroides e terpenoides em todos os extratos avaliados neste estudo. Observou-se que os extratos da E. spectabile, B. laciniosa e $N$. variegata apresentaram atividade antimicrobiana, com as seguintes médias para a concentração bactericida mínima: 11.379, 11.405 e $11.995 \mu \mathrm{g} /$ $\mathrm{mL}$, respectivamente. Observou-se maior atividade inibitória para as espécies $A$. cearensis e $H$. martiana, que inibiram 88,1 e 99,4 \% dos isolados, respectivamente. O extrato etanólico da $S$. convoluta apresentou o menor percentual de inibição, sendo igual a $15 \%(n=24 / 160)$. Considerando o potencial antibacteriano destas plantas do bioma Caatinga frente à Staphylococcus isolados de casos de mastite subclínica em caprinos e ovinos, outros estudos sobre a atividade in vivo devem ser realizados.

Palavras-chave: Extrato natural. Caprinos. Ovinos. Infecção intramamária. Terapia.

\footnotetext{
*Corresponding author

${ }^{1}$ Received for publication in 10/02/2014; accepted in 02/03/2016.

Paper extracted from the Master of Science dissertation of the first author.

${ }^{2}$ Department of Animal Science, Instituto Federal de Educação, Ciência e Tecnologia do Sertão Pernambucano, Petrolina, PE, Brazil; rmpeixoto.vet@gmail.com.

${ }^{3}$ Department of Animal Science, Universidade Federal do Vale do São Francisco, Petrolina, PE, Brazil; tonerasmo29@hotmail.com, jackson.guedes@univasf.edu.br,mateus.costa@univasf.edu.br.

${ }^{4}$ Department of Health, Universidade Estadual de Feira de Santana, Feira de Santana, BA, Brazil; branco@uefs.br.
} 


\section{INTRODUCTION}

The phenomenon of bacterial resistance began around $1950 \mathrm{~s}$ when antibiotics came to be widely used. Since then, this problem has gained considerable importance in relation to public health (LEVY, 2002). These infections lead to significant economic losses (KÜMMERER, 2004).

The antibacterial activity of natural plant extracts and some of their compounds against isolates obtained from cases of mastitis has been previously demonstrated. A number of producers and veterinarians have used medicinal plants to prevent and treat mastitis. There is a clear predominance of practices directed toward treatment, including the local use of plant-based solutions or medicinal salves or the oral administration of fresh or dry plants (SCHUCH et al., 2008).

A number of studies have demonstrated the antimicrobial activity of ethanolic extracts of plants from Northeastern Brazil flora, particularly the Caatinga biome (NOGUEIRA et al., 2001; MAIGA et al., 2005; MORAES et al., 2006). In vitro studies were conducted to determine the antimicrobial potential of Brazilian flora, and yielded satisfactory results (GRANATO et al., 2005; USHIMARU et al., 2007). However, the discontinuity of these studies and the fragmentation of results did not favor the advances in this area.

Therefore, the aim of the present study was to assess the in vitro antibacterial potential of ethanolic extracts from six plants of the Caatinga biome against isolates of Staphylococcus spp. obtained from cases of subclinical mastitis among goats and ewes raised in the Brazilian states of Pernambuco and Bahia.

\section{MATERIAL AND METHODS}

The botanical material was collected in the district of Petrolina (PE) and identified by the botanist André Paviotti Fontana from the Centro de Referência para Recuperação de Áreas Degradadas - CRAD) of the Universidade Federal do Vale do São Francisco. Dried herbarium specimens were deposited in the Vale do São Francisco Herbarium (HVASF), with codes for the following species: Encholirium spectabile Mart. (6443), Bromelia laciniosa Mart. (6442), Neoglaziovia variegata Mez. (6441), Amburana cearensis (Fr. Allem) A.C.Smith (5445), Hymenaea martiana Hayne (6444), and Selaginella convoluta Spring (6440).

The dry plant matter was ground to powder and was submitted to maceration with $95 \%$ ethanol in a stainless-steel container. Several extractions were made with an interval of 72 hours between each extraction and the successive one, until complete depletion of the plant material. The obtained extract solution was passed through a solvent distillation process in a reduced pressure rotary evaporator at a mean temperature of $50^{\circ} \mathrm{C}$. After the evaporation of the solvent, the crude ethanolic extract (CEE) was obtained.

All extracts were submitted to phytochemical screening to identify the main classes of chemical constituents. Preliminary phytochemical screening was performed using the methodology described by Matos (1997) or Falkenberg et al. (2003). Tests were undertaken to identify phenols, flavonoids, tannins, alkaloids, saponins, steroids, and triterpenoids.

One-hundred and sixty Staphylococcus spp. were obtained from cases of subclinical mastitis in dairy ewes $(n=40)$ and goats $(n=125)$ from the farms in the Brazilian states of Pernambuco $(n=03)$ and Bahia $(n=22)$. The animals were raised in intensive or semi-intensive systems. Bacteria were identified according to morphology, biochemical tests, and dyeing. For identification of isolates belonging to the Staphylococcus genus, biochemical tests were carried out, such as coagulase, DNase, semi-solid glucose, mannitol fermentation, purple agar base, esculin hydrolysis, and urease tests (HOLT et al., 1994).

A quantity of $0.25 \mathrm{~g}$ of each ethanolic extract was weighed and diluted in $10 \mathrm{~mL}$ of sterile distilled water, obtaining a stock solution of $25 \mathrm{mg} / \mathrm{mL}$. The minimal bactericidal concentration (MBC) was determined according to document M7-A7 (CLSI, 2008); $200 \mu \mathrm{L}$ of Muller-Hinton Agar was added to microtiter plates. Subsequently, $200 \mu \mathrm{L}$ of the extract stock solution was added to the first well and after homogenization, transferred to the second and so on successively, obtaining the following final concentrations $12,500,6,250,3,125,1,562.5,781.2$, 390.6, 195.3, and $97.6 \mu \mathrm{g} / \mathrm{mL}$.

While preparing the inoculum, colonies in Muller-Hinton Agar were used to prepare a bacterial suspension with turbidity equivalent to the McFarland standard 0.5. Ten microliters of this suspension was inoculated in the microplate wells containing the ethanolic extract dilution. The plate was incubated at $37^{\circ} \mathrm{C}$ for $24 \mathrm{~h}$ under aerobiosis. To determine $\mathrm{MBC}$, an aliquot of $10 \mu \mathrm{L}$ was seeded on the surface of the Muller-Hinton agar. After $48 \mathrm{~h}$ of incubation at $35^{\circ} \mathrm{C}$, the $\mathrm{MBC}$ was defined as the lowest concentration of the ethanolic extract required that kills the bacterium. All tests were undertaken in triplicate. A methicillin-resistant Staphylococcus aureus (MRSA) strain was used, as recommended by Cos et al. (2006).

Six types of ethanolic extracts were used: EEEs = ethanolic extract of Encholirium spectabile; $\mathrm{EEBl}=$ ethanolic extract of Bromelia laciniosa; $\mathrm{EENv}=$ ethanolic extract of Neoglaziovia variegate; EEAc $=$ ethanolic extract of Amburana cearensis; $\mathrm{EEHm}=$ ethanolic extract of Hymenaea martiana, and $\mathrm{EESc}=$ ethanolic extract of Selaginella convoluta. Each bacterial isolate was considered as a 
unit and the tests were performed in triplicate. The mean $\mathrm{MBC}$ value obtained from each bacterial isolate was considered as the response variable. Antimicrobial activity that exhibited a $P$ value of less than $5 \%(P<0.05)$ according to the null hypothesis was subjected to the Kruskal-Wallis test, followed by Dunn's test to compare the median MBC values using software BioEstat 5.3.

\section{RESULTS AND DISCUSSION}

The presence of phenolic components, flavonoids, steroids, and terpenoids was verified for all the tested extracts. The mean MBC values of the various ethanolic extracts for the MRSA strain were EEE $(10,417 \mu \mathrm{g} / \mathrm{mL})$, EEBl $(10,417 \mu \mathrm{g} / \mathrm{mL})$, EEAc $(12,500 \mu \mathrm{g} / \mathrm{mL})$, and EEHm $(10,417 \mu \mathrm{g} / \mathrm{mL})$. EENv and EESc did not show any activity.

E. spectabile, B. laciniosa, and N. variegate from the Bromeliaceae family exhibited antimicrobial activity against the Staphylococcus isolates, with mean MBC values of $11,379 \mu \mathrm{g} / \mathrm{mL}$, $11,405 \mu \mathrm{g} / \mathrm{mL}$, and $11,995 \mu \mathrm{g} / \mathrm{mL}$, respectively (Table 1). E. spectabile exhibited the highest activity, inhibiting $49.9 \%$ of the Staphylococcus isolates.

Table 1. Susceptibility of Staphylococcus isolates to the ethanolic extracts of plants from Caatinga vegetation.

\begin{tabular}{|c|c|c|c|}
\hline \multirow{2}{*}{ Family/Species } & \multirow{2}{*}{ Activity (\%) } & \multicolumn{2}{|c|}{ Minimal Bactericidal Concentration } \\
\hline & & Range & Median* $(\mu \mathrm{g} / \mathrm{mL})$ \\
\hline Bromeliaceae & & & \\
\hline Encholirium spectabile & $49.9(79 / 160)$ & $3,125-12,500$ & $12,500^{\mathrm{b}}$ \\
\hline Bromelia laciniosa & $36.9(59 / 160)$ & $3,125-12,500$ & $12,500^{\mathrm{b}}$ \\
\hline $\begin{array}{c}\text { Neoglaziovia variegata } \\
\text { Fabaceae }\end{array}$ & $20.6(33 / 160)$ & $6,250-12,500$ & $12,500^{\mathrm{b}}$ \\
\hline $\begin{array}{c}\text { Amburana cearensis } \\
\text { Caesalpinaceae }\end{array}$ & $88.1(141 / 160)$ & $3,125-12,500$ & $12,500^{\mathrm{b}}$ \\
\hline $\begin{array}{l}\text { Hymenaea martiana } \\
\text { Selaginellaceae }\end{array}$ & $99.4(159 / 160)$ & $390.62-12,500$ & $2,083^{\mathrm{a}}$ \\
\hline Selaginella convoluta & $15.0(24 / 160)$ & $6,250-12,500$ & $12,500^{b}$ \\
\hline
\end{tabular}

*Medians followed by the same letter do not differ statistically $(P>0.05)$.

The highest inhibitory activities were recorded for $A$. cearensis and $H$. martiana. The mean MBC value recorded for the ethanolic extract of $A$. cearensis was $10,934 \mu \mathrm{g} / \mathrm{ml}$, whereas that for the ethanolic extract of $H$. martiana was significantly lower $(2,811 \mu \mathrm{g} / \mathrm{mL})$ than that observed for the other extracts. The ethanolic extract of $S$. convoluta exhibited the lowest percentage of inhibition $15 \%$ ( $n=24 / 160)$. The mean $M B C$ value was 12,066 $\mu \mathrm{g} /$ $m L$, ranging from 6,250 to $12,500 \mu \mathrm{g} / \mathrm{mL}$.

The following percentages of sensitivity were observed for the coagulase-negative and positive Staphylococcus (CNS and CPS) species: $E$. spectabile (32.5 and 16.9\%); B. laciniosa (25.0 and $11.9 \%) ; N$. variegata (16.3 and $4.4 \%)$; A. cearensis (54.4 and $33.8 \%)$; H. martiana (63.8 and $35.6 \%)$, and $S$. convoluta $(14.4$ and $0.6 \%)$, for CNS $(n=33)$ and CPS $(\mathrm{n}=78)$, respectively (Figure 1).

Concerning the mean MBC values, the following results were obtained for CNS and CPS, respectively: E. spectabile (10,958 and $12,191 \mu \mathrm{g} /$ $\mathrm{mL}) ; B$. laciniosa $(11,433$ and $11,343 \mu \mathrm{g} / \mathrm{mL}) ; N$. variegata $(11,859$ and $12,500 \mu \mathrm{g} / \mathrm{mL}) ; A$. cearensis $(10,896$ and $10,995 \mu \mathrm{g} / \mathrm{mL}) ; H$. martiana $(2,600$ and $3,189 \mu \mathrm{g} / \mathrm{mL})$, and $S$. convoluta $(12,228$ and 8,333 $\mu \mathrm{g} / \mathrm{mL}$ ) (Figure 2).

The mean $\mathrm{MBC}$ values for $E$. spectabile, $B$. laciniosa, and $N$. variegata of the Bromeliaceae family were $11,379 \mu \mathrm{g} / \mathrm{mL}, 11,405 \mu \mathrm{g} / \mathrm{mL}$, and $11,995 \mu \mathrm{g} / \mathrm{mL}$, respectively. Aligianis et al. (2001) proposed the following classification for plant extracts, based on the results of the $\mathrm{MBC}$, strong inhibition - MBC up to $500 \mu \mathrm{g} / \mathrm{mL}$; moderate inhibition - MBC from 600 to $1,500 \mu \mathrm{g} / \mathrm{m}$; weak inhibition - MBC above 1,600 $\mu \mathrm{g} / \mathrm{mL}$. Nevertheless, this classification is subjective and does not take into consideration several factors that may affect the MBC, including the variability and availability of the bioactive compounds in the extracts. According to Duarte (2007), there is no consensus regarding the acceptable level of inhibition for natural products when compared with standard antibiotics; therefore, some authors only consider results similar to those obtained with antibiotics, while others consider plants producing greater inhibition than antibiotics as having good potential.

Despite the high concentrations recorded, the presence of antimicrobial activity in the three species of plants belonging to the Bromeliaceae family indicated the existence of compounds active against bacterial isolates. Different classes of organic compounds were reported, including triterpenes, steroids, flavonoids, glycerols, and derivatives of cinnamic acids (MANETTI et al., 2009). The same authors reviewed the metabolites of the Bromeliaceae family and noted that only few species have been investigated for their chemical components thus far. From a pharmacological point of view, few studies have been described in the literature. 


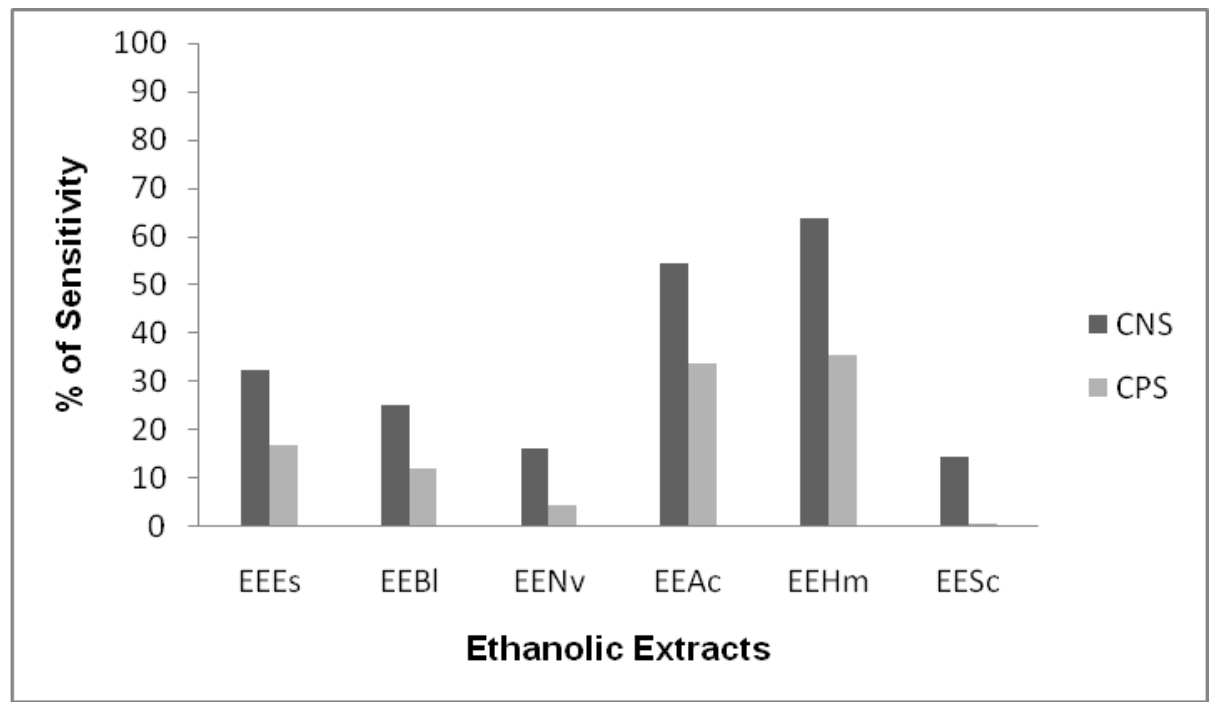

Figure 1. Percentages of sensitivity of coagulase-negative and positive Staphylococcus (CNS and CPS) to plant extracts from Caatinga vegetation: EEEs = ethanol extract of Encholirium spectabile; EEBl = ethanol extract of Bromelia laciniosa $; \mathrm{EENv}=$ ethanol extract of Neoglaziovia variegata $; \mathrm{EEAc}=$ ethanol extract of Amburana cearensis; $\mathrm{EEHm}=$ ethanol extract of Hymenaea martiana; EESc = ethanol extract of Selaginella convoluta.

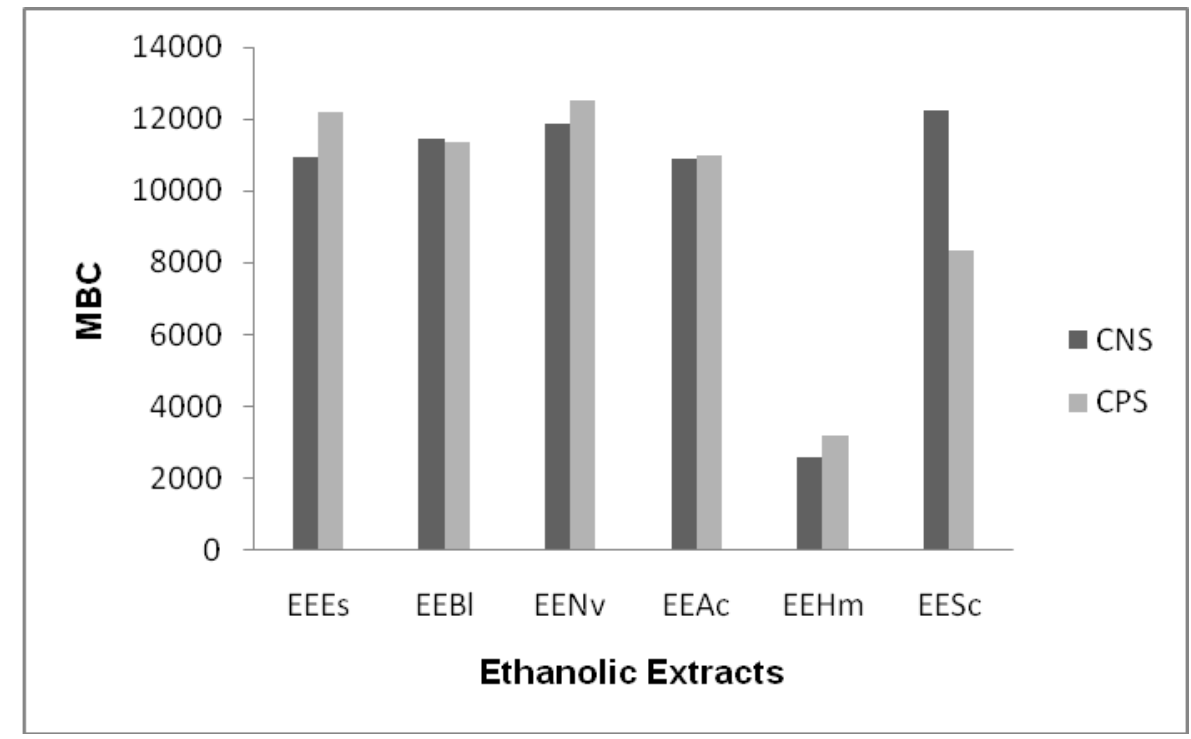

Figure 2. Mean MBC values of extracts of flora from Caatinga vegetation against coagulase-negative and positive Staphylococcus (CNS and CPS): EEEs = ethanol extract of Encholirium spectabile; EEBl = ethanol extract of Bromelia laciniosa; $\mathrm{EENv}=$ ethanol extract of Neoglaziovia variegata $; \mathrm{EEAc}=$ ethanol extract of Amburana cearensis; EEHm = ethanol extract of Hymenaea martiana; EESc = ethanol extract of Selaginella convoluta.

A. cearensis and $H$. martiana showed the highest percentage of inhibition (88.1\% and $99.4 \%$, respectively). Other studies focused on the husk of the stalk of $A$. cearensis, the main part of the plant used in popular remedies, showed the presence of many phenolic compounds in the plant, particularly flavonoids (CANUTO; SILVEIRA, 2006). These phenolic compounds, in addition to coumarin, may be responsible for the pharmacological activity of the species, as observed in tests performed with pure substances (LEAL et al., 2005).
The antimicrobial activity of EEHm was favorable, with a mean $\mathrm{MBC}$ value of $2,811 \mu \mathrm{g} / \mathrm{mL}$. Phytochemical studies detected the presence of diterpenes in the resin exudes from the trunk and in the extracts of the stem bark of $H$. courbaril (NOGUEIRA et al., 2001).

The lowest inhibition percentage of EESc corroborates the findings of Hirai and Prado (2000). According to these authors, studies involving the Selaginellaceae family in Brazil are rare. The preliminary phytochemical screening of this species 
revealed the presence of steroids, terpenoids, and flavonoids, with analgesic and anti-inflammatory activities (MORAES et al., 2006). However, this pteridophyte exhibited poor antimicrobial activity against the isolates of Staphylococcus at the dosage tested in the present study.

The fact that there was a greater percentage of sensitivity of the CNS to all extracts is a significant result since the phenomenon of resistance has been observed for different antimicrobial drugs in many isolates of CNS (TAPONEN; PYÖRÄLÄ, 2009).

The study of the potential of ethanolic extracts of plants from the Northeast of Brazil is relevant for the further development of these medicinal plants. In addition, the present study serves as a point of departure from obtaining synthetic or biosynthetic compounds. There are compounds that exhibit greater or different biological activity than their isolated components (BÔAS; GADELHA, 2007). Resistance to antibiotics is a worldwide problem; therefore, there is an urgent need for new therapeutic agents. Flavonoids are a family of compounds derived from plants with potentially exploitable activities, including antibacterial activity and synergism with antibiotics (CUSHNIE; LAMB, 2011).

\section{CONCLUSIONS}

The present study demonstrated the antimicrobial activity of the ethanolic extract of the six plants assessed. Nevertheless, studies with fractions of these extracts are necessary, thereby reducing the concentrations tested. The antibacterial activity could be related to the classes of secondary metabolites, particularly flavonoids. Considering the low cost of phytotherapy and the activity of the plants from the Caatinga biome against the causative pathogens of mastitis in goats and ewes, further studies focusing on in vitro activity and phytochemical characterization are necessary, in addition to assessments of the toxicological aspects of these plants.

\section{ACKNOWLEDGEMENTS}

The authors of the present study would like to thank FACEPE for granting scholarship for graduate studies (R.M. Peixoto); FAPESB for granting scholarship for scientific initiation (W.E. Lima Silva); and IDR sisal for financial support and ceding facilities.

\section{REFERENCES}

ALIGIANIS, N. et al. Composition and antimicrobial activity of the essential oil of two Origanum species. Journal of Agricultural and Food Chemistry, Washington, v. 49, n. 9, p. 4168 4170, 2001.

BÔAS, G. K. V.; GADELHA, C. A. G. Oportunidades na indústria de medicamentos e a lógica do desenvolvimento local baseado nos biomas brasileiros: bases para a discussão de uma política nacional. Cadernos de Saúde Pública, Rio de Janeiro, v. 23, n. 6, p. 1463-1471, 2007.

CANUTO, K. M.; SILVEIRA, E. R. Constituintes químicos da casca do caule de Amburana cearensis A. C. SMITH. Química Nova, São Paulo, v. 29, n. 6, p. 1241-1243, 2006.

Levy, S. B. Factors impacting on the problem of antibiotic resistance. Journal Antimicrobial Chemotherapy, Oxford, v. 49, n. 1, p. 25-30, 2002.

CLSI. Performance standards for antimicrobial disk and dilution susceptibility tests for bacteria isolated from animals. Clinical and Laboratory Standards Institute. Approved Standard, 3rd ed. CLSI/NCCLS document M31 - A3. Wayne, 2008.

COS, P. et al. Anti-infective potential of natural products: How to develop a stronger in vitro 'proofof-concept'. Journal of Ethnopharmacology, Amsterdã, v. 106, n. 3, p. 290-302, 2006.

CUSHNIE, T. P. T.; LAMB, A. J. Recent advances in understanding the antibacterial properties of flavonoids. International Journal Antimicrobial Agents, Amsterdã, v. 38, n. 2, p. 99-107, 2011.

DUARTE, M. C. T. Atividade antimicrobiana de plantas medicinais e aromáticas utilizadas no Brasil. Multiciência, Campinas, v. 7, n. 10, p. 1-16, 2006.

FALKENBERG, M. B.; SANTOS, R. I.; SIMÕES, C. M. O. Introdução à análise fitoquímica. In.: SIMÕES et al. Farmacognosia: da planta ao medicamento. 5 ed. Porto Alegre/Florianópolis: Ed. UFRGS/Ed. UFSC, 2003. p. 165-181.

GRANATO, D. et al. Chemical and biological evaluation of rejects from the wood industry. Brazilian Archives of Biology and Technology, Curitiba, v. 48, p. 237-241, 2005.

HIRAI, R.Y.; PRADO, J. Selaginellaceae Willk. no Estado de São Paulo, Brasil. Revista Brasileira de Botânica, São Paulo, v. 23, n. 3, p. 313-339, 2000.

HOLT J. G. Bergey's manual of determinative bacteriology. Williams \& Wilkins, Baltimore, 1994, $787 \mathrm{p}$. 
KÜMMERER, K. Resistance in the environment. Journal of Antimicrobial Chemotherapy, Oxford, v. 54, n. 2, p. 311-320, 2004.

LEAL, L. K. A. M. et al. Amburoside A, a glucoside from Amburana cearensis protects mesencephalic cells against 6-hydroxydopamine-induced neurotoxicity. Neuroscience Letters, Irlanda, v. 388 , n., 2, p. 86-90, 2005.

MAIGA, A. et al. A survey of toxic plants on the market in the district of Bamako, Mali: traditional knowledge compared with a literature search of modern pharmacology and toxicology. Journal of Ethnopharmacology, Amsterdã, v. 96, n. 1-2, p. 183-193, 2005.

MANETTI, L. M.; DELAPORTE, R. H.; JAVERDE JUNIOR, A. Metabólitos secundários da família Bromeliaceae. Química Nova, São Paulo, v. 32, n. 7, p. 1-13, 2009.

MATOS, F. J. A. Introdução à fitoquímica experimental. 2. ed. Fortaleza, CE: UFC, 1997. 141 p.

MORAES, A. C. A. et al. Triagem fitoquímica e atividade antinociceptiva do extrato etanólico bruto de Selaginella convoluta (Arn.) Spring (Selaginellacae). In: SIMPÓSIO DE PLANTAS MEDICINAIS DO BRASIL, 19, 2006, Salvador, BA. Anais... Salvador, 2006.

NOGUEIRA, R. T. et al. Clerodane-type diterpenes from the seed pods of Hymenaea courbaril var. stilbocarpa. Phytochemistry, Londres, v. 58, n. 8, p. 1153-1157, 2001.

SCHUCH, L. F. D. et al. Cinética da atividade antibacteriana in vitro de extratos naturais frente a micro-organismos relacionados à mastite bovina. Ciência Animal Brasileira, Goiânia, v. 9, n. 1, p. 161-169, 2008.

TAPONEN, S.; PYÖRÄLÄ, S. Coagulase-negative staphylococci as cause of bewes mastitis - Not so different from Staphylococcus aureus? Veterinary Microbiology, Amsterdã, v. 134, n. 1-2, p. 29-36, 2009.

USHIMARU, P. I. et al. Antibacterial activity of medicinal plant extracts. Brazilian Journal of Microbiology, São Paulo, v. 38, n. 4, p. 717-719, 2007. 